\title{
Nickel basic salts as inorganic precursors in the production of nickel
}

\author{
A. LÓPEZ-DELGADO, S. LÓPEZ-ANDRÉS, O. GARCIA-MARTINEZ, \\ P. MILLAN, R. M. ROJAS \\ Instituto Química Inorgánica "Elhúyar", CS/C, Serrano 113, 28006 Madrid, Spain
}

The utilization of some nickel basic salts, nickel hydroxychloride and nickel hydroxynitrate, as inorganic precursors in the obtention of nickel powder, has been studied. When these materials are thermally decomposed in an X-ray high-temperature diffraction chamber, pure nickel is formed as the only compound at about $700^{\circ} \mathrm{C}$ but if nickel hydroxide is the starting material, small amounts of nickel oxide are always present even if the temperature is raised up to $900^{\circ} \mathrm{C}$.

\section{Introduction}

Because of the many applications of nickel powder, especially as a catalyst, a great deal of work has been done regarding the obtention of this metal. The production of nickel by the thermal decomposition of some organic and organometallic nickel compounds, as well as the reduction of nickel hydroxyde with hydrogen, are among the most usual chemical procedures [1-14].

In a previous paper [15] we have shown that copper powder can be easily obtained from an inorganic precursor, copper hydroxychloride, when it is decomposed in an X-ray high temperature diffraction chamber. We have now extended the study to two nickel basic salts, nickel hydroxychloride and nickel hydroxynitrate, and the results have been compared with those obtained when nickel hydroxyde is the inorganic precursor.

\section{Experimental procedure}

\subsection{Synthesis}

Nickel hydroxychloride was obtained by a procedure that consists in the hydrolysis of $20 \mathrm{ml}$ of a $4 \mathrm{M}$ solution of $\mathrm{NiCl}_{2} \cdot 6 \mathrm{H}_{2} \mathrm{O}$ with $0.5 \mathrm{~g}$ of nickel oxide recently prepared. The grey-green precipitate thus formed was aged at room temperature for six months in the mother liquor, filtered off, washed with water, ethanol and acetone, dried in vacuum and kept over $\mathrm{P}_{2} \mathrm{O}_{5}$. The analytical results were as follows: found (wt \%) $\mathrm{Ni} 42.34, \mathrm{Cl} 25.57, \mathrm{H}$ 3.01. From the observation of the infrared spectrum of this compound, the presence of water and $\mathrm{OH}^{-}$groups are clearly inferred, and the results of the chemical analysis are in favour of a formulation for this product such as $\mathrm{Ni}(\mathrm{OH}) \mathrm{Cl} \cdot 1.5$ $\mathrm{H}_{2} \mathrm{O}$. (Calculated (wt \%) Ni 42.49, C1 25.65, H 2.89).

On the other hand, the X-ray diffraction pattern of this compound agree with that reported by Feitknecht and Collet [16] for the Type III nickel hydroxychloride $\mathrm{NiCl}_{2} \cdot 2 \mathrm{Ni}(\mathrm{OH})_{2} \cdot 3$ to $4 \mathrm{H}_{2} \mathrm{O}$ and, even though the analytical results support a $1: 1 \mathrm{NiCl}_{2}: \mathrm{Ni}(\mathrm{OH})_{2}$ stoichiometric relationship, the $\mathrm{X}$-ray diffraction data as well as the results of thermal studies prevent us from rejecting the Feitknecht and Collet formulation.

The X-ray diffraction data of this material are given in Table I. The X-ray pattern has been indexed within a monoclinic cell and the calculated cell dimensions have been refined by least-square calculations. The electron microscopy observations indicate that this product is a single phase and Fig. 1 shows a representative micrograph.

The synthesis of anhydrous nickel hydroxynitrate was first attempted by solid-state thermal decomposition $[17,18]$ in which $\mathrm{Ni}\left(\mathrm{NO}_{3}\right)_{2} \cdot 6 \mathrm{H}_{2} \mathrm{O}$ is decomposed at a very low heating rate $\left(5^{\circ} \mathrm{C}\right.$ in $\left.48 \mathrm{~h}\right)$ up to $160^{\circ} \mathrm{C}$.

On the other hand, we have also obtained this compound, which has been reported as a non-stoichiometric nickel hydroxynitrate [19], by adding to a $0.3 \mathrm{M}$ solution of $\mathrm{Ni}\left(\mathrm{NO}_{3}\right)_{2} \cdot 6 \mathrm{H}_{2} \mathrm{O}$ a $0.2 \mathrm{M}$ solution of urea with continous stirring. The resulting solution is kept boiling until nickel hydroxynitrate precipitates and

TABLE I X-ray powder data for nickel hydroxychloride $(a=0.7514(2) \mathrm{nm} ; \quad b=1.2125(3) \mathrm{nm} ; \quad c=1.0486(2) \mathrm{nm} ; \quad \beta=$ $\left.101.40(1)^{\circ} ; V=0.9355(2) \mathrm{nm}^{3}\right)$

\begin{tabular}{lllr}
\hline$d_{\text {ots }}(\mathrm{nm})$ & $d_{\text {cak }}(\mathrm{nm})$ & $h k l$ & $I_{0} / I$ \\
\hline 1.033 & 1.0269 & 001 & 77 \\
0.735 & 0.7358 & 100 & 38 \\
0.665 & 0.6652 & I0 & 4 \\
0.548 & 0.5479 & 101 & 100 \\
0.467 & 0.4678 & T 02 & 7 \\
0.386 & 0.3860 & 102 & 52 \\
0.368 & 0.3679 & 200 & 4 \\
0.342 & 0.3423 & 003 & 6 \\
0.338 & 0.3376 & I03 & 12 \\
0.326 & 0.3261 & 201 & 15 \\
0.298 & 0.2981 & 023 & 8 \\
0.292 & 0.2916 & 222 & 23 \\
0.280 & 0.2803 & 140 & 11 \\
0.259 & 0.2593 & I04 & 11 \\
0.2494 & 0.24967 & 222 & 6 \\
0.2404 & 0.24041 & 310 & 58 \\
0.2339 & 0.23394 & 240 & 64 \\
0.2245 & 0.22451 & 114 & 33 \\
0.2021 & 0.20208 & 060 & 39 \\
0.1932 & 0.19335 & I 61 & 35 \\
0.1874 & 0.18745 & 225 & 9 \\
\hline
\end{tabular}




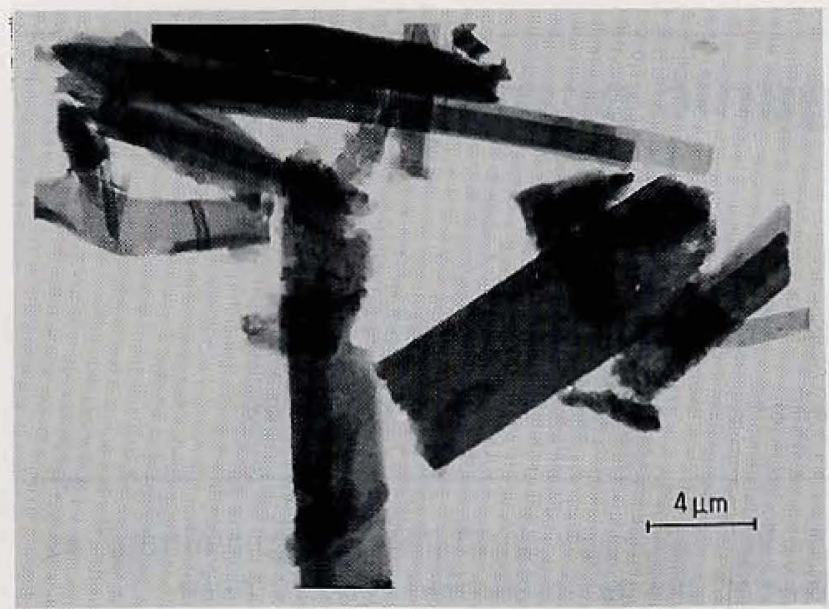

Figure 1 Electron micrograph of nickel hydroxychloride.

$\mathrm{CO}_{2}$ evolution has ceased. The precipitate is filtered off and washed thoroughly with cold water, alcohol and vacuum-dried until the adsorbed $\mathrm{CO}_{2}$ has been completely removed. The $\mathrm{X}$-ray powder diagram and the infrared spectrum of this material are identical to those recorded for the product obtained by solid-state thermal decomposition and agree with the reported data [20].

Nickel hydroxide was obtained by adding a $1 \mathrm{M}$ solution of $\mathrm{NaOH}$ to a $0.3 \mathrm{M}$ solution of $\mathrm{Ni}\left(\mathrm{NO}_{3}\right)_{2}$. $6 \mathrm{H}_{2} \mathrm{O}$; the precipitate was washed with cold water and dried overnight at $100^{\circ} \mathrm{C}$. The X-ray pattern is that of $\beta-\mathrm{Ni}(\mathrm{OH})_{2}[21,22]$ and the infrared spectrum indicates that the material has a nearly "free" hydroxyl group $[23,24]$.

All reagents were of analytical reagent grade.

\subsection{Equipment}

The $\mathrm{X}$-ray diffraction diagrams were recorded on a Siemens D-500 diffractometer with $\mathrm{CuK} \alpha$ radiation and silicon powder ( $99.99 \%$ purity) as internal standard. The infrared spectra were obtained in the 4000 to $200 \mathrm{~cm}^{-1}$ range in a Perkin-Elmer 325 spectrophotometer on potassium bromide or caesium iodide pellets. Electron micrographs were obtained with a
TABLE II Infrared absorption band frequencies of nickel hydroxychloride

\begin{tabular}{llll}
\hline Assignment & \multicolumn{3}{l}{ Frequencies $\left(\mathrm{cm}^{-1}\right)$} \\
\cline { 2 - 4 } & Room temperature & $180^{\circ} \mathrm{C}$ & $280^{\circ} \mathrm{C}$ \\
\hline$v(\mathrm{OH})$ & $3600 \mathrm{sh}$ & $3622 \mathrm{vs}$ & $3600 \mathrm{vs}$ \\
& $3580 \mathrm{vs}$ & $3581 \mathrm{vs}$ & \\
$v_{\mathrm{as}}\left(\mathrm{H}_{2} \mathrm{O}\right)$ & $3500 \mathrm{vs}$ & $3500 \mathrm{vs}$ & \\
$v_{\mathrm{s}}\left(\mathrm{H}_{2} \mathrm{O}\right)$ & $3250 \mathrm{~s}, \mathrm{bd}$ & $3222 \mathrm{vs}$ & \\
$\delta(\mathrm{HOH})$ & $1610 \mathrm{~m}$ & $1613 \mathrm{~m}$ & \\
$\delta(\mathrm{Ni}-\mathrm{O}-\mathrm{H})$ & $820 \mathrm{sh}$ & $790 \mathrm{sh}$ & \\
& $780 \mathrm{sh}$ & $700 \mathrm{~s}$ & $670 \mathrm{~s}$ \\
& $720 \mathrm{sh}$ & $615 \mathrm{~s}$ & \\
& $675 \mathrm{sh}$ & & \\
$v(\mathrm{Ni}-\mathrm{O})$ and & $605 \mathrm{~s}$ & $452 \mathrm{~m}$ & $450 \mathrm{~m}$ \\
$\delta(\mathrm{Cl}-\mathrm{Ni}-\mathrm{O})$ & $405 \mathrm{~s}$ & $411 \mathrm{~s}$ & $370 \mathrm{~s}$ \\
& $350 \mathrm{~s}$ & $365 \mathrm{~s}$ & \\
\hline
\end{tabular}

vs $=$ Very strong; $s=$ strong; $s h=$ shoulder; $b d=$ broad; $\mathrm{m}=$ medium.

Siemens El miskop 102 microscope and the samples were dispersed in $\mathrm{n}$-butanol. The thermograms were obtained in a Stanton 781 Simultaneous Thermal Analysis System. About $10 \mathrm{mg}$ of the samples were pyrolysed in platinum-rhodium wells up to $800^{\circ} \mathrm{C}$ both in air and nitrogen flows $\left(50 \mathrm{ml} \mathrm{min}^{-1}\right)$ at several heating rates $\left(2,10^{\circ} \mathrm{C} \mathrm{min}^{-1}\right)$ and precalcined; alumina was the inert reference. The X-ray high temperature diffraction studies were performed on an Anton PAAR HTK 10 chamber mounted on a Philips PW 1310 equipment with a tantalum strip as the heating element. Experimental details have been published elsewhere [15].

\section{Results and discussion}

\subsection{Thermal studies}

Thermal decomposition of nickel hydroxychloride was carried out in atmospheres of still air or nitrogen and Figs $2 \mathrm{a}$ and $\mathrm{b}$ present the thermograms recorded. The compound decomposes in a stepwise manner to yield at about $280^{\circ} \mathrm{C}$ both in air and nitrogen an intermediate; the X-ray diffraction pattern (Fig. 4b

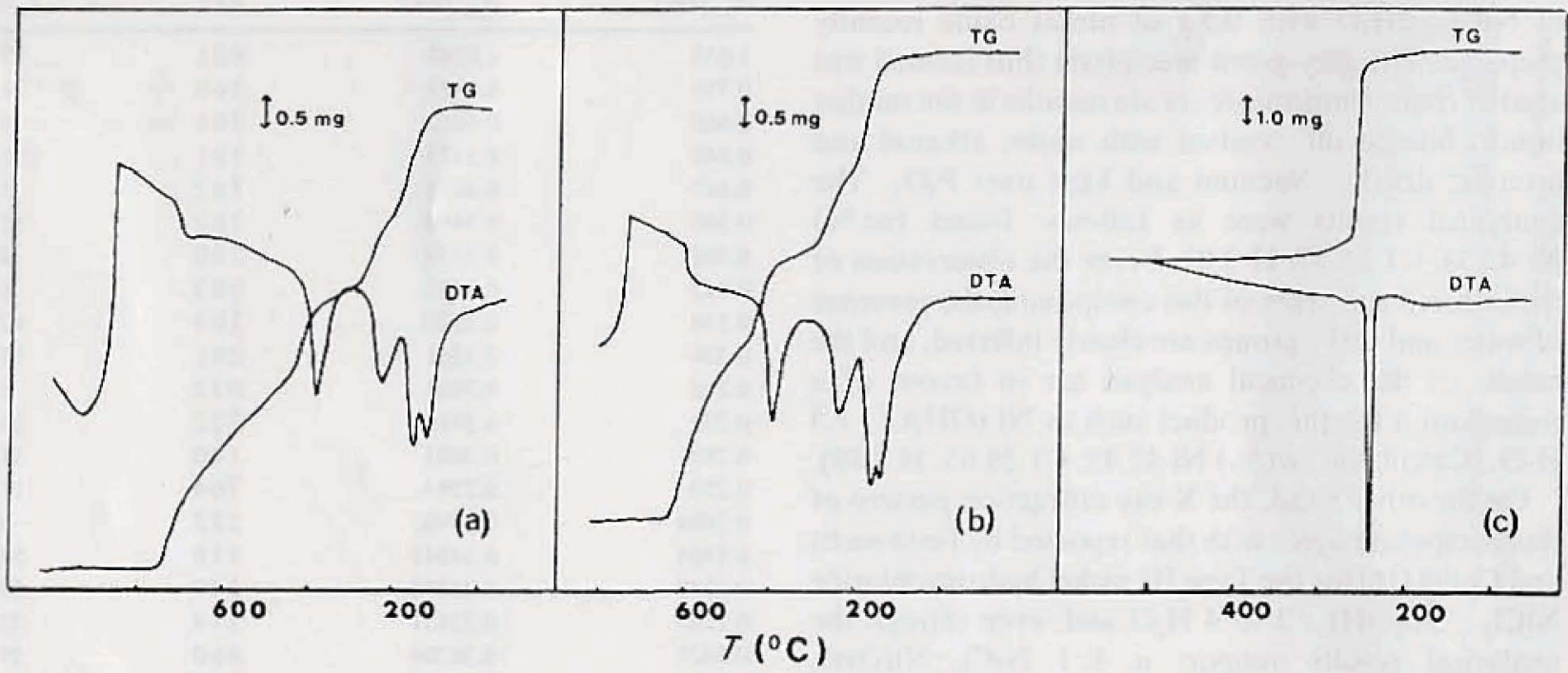

Figure 2 Differential thermal analysis (DTA) and thermogravimetric (TG) curves of nickel hydroxychloride in (a) nitrogen and (b) still air; (c) nickel hydroxynitrate in flowing air. Heating rate $10^{\circ} \mathrm{C} \mathrm{min}^{-1}$. 


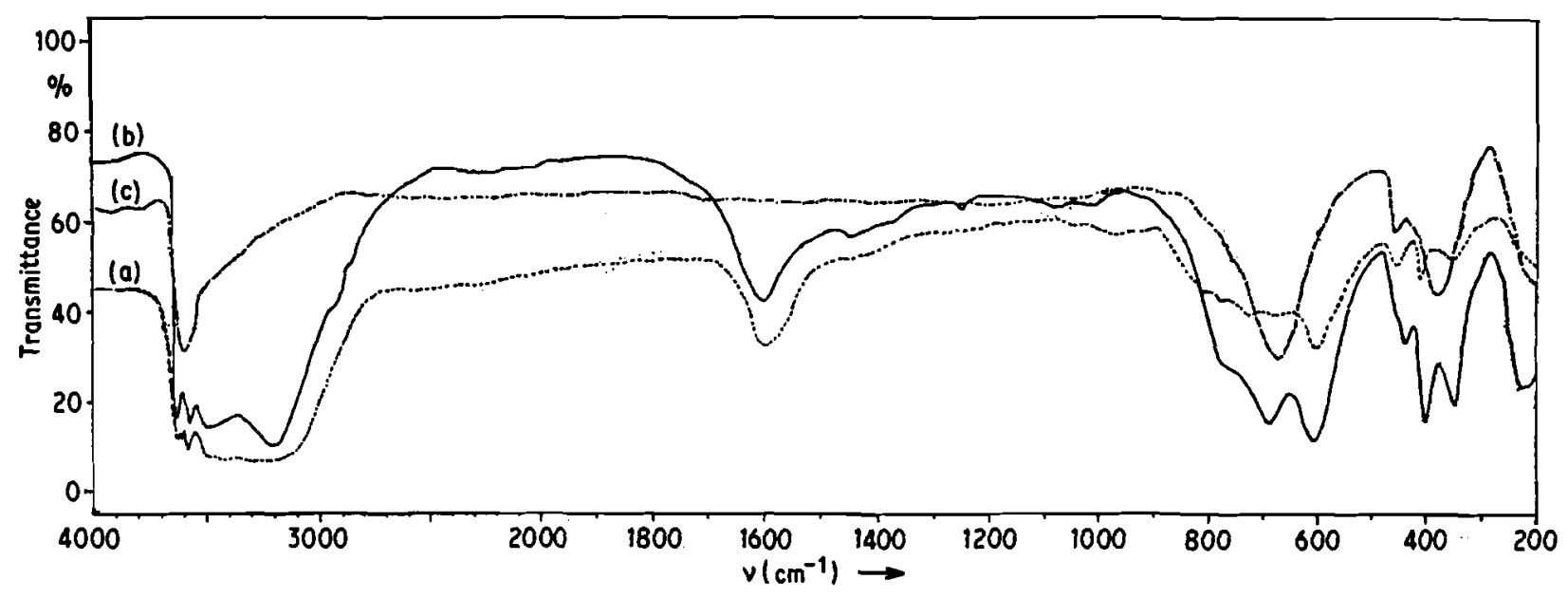

Figure 3 Infrared spectra of (a) ( $\cdots)$ nickel hydroxychloride, (b) (-) heated at $180^{\circ} \mathrm{C}$, (c) (-.-) heated at $280^{\circ} \mathrm{C}$.

below) agrees with that reported by Feitknecht and Collet $[16,25]$ for Type II nickel hydroxychloride, whose composition ranges from $\mathrm{NiCl}_{0.38}(\mathrm{OH})_{1.62}$ to $\mathrm{NiCl}_{0.68}(\mathrm{OH})_{1.32}$, with hexagonal cell parameters $a=$ 0.315 to $0.316_{5} \mathrm{~nm}, c=0.543$ to $0.544_{5} \mathrm{~nm}$, respectively. The observed weight loss at this stage is $18.22 \%$.

The infrared spectra of the initial compound and of intermediates isolated at 180 and $280^{\circ} \mathrm{C}$ are shown in Fig. 3. The absorption bands have been tentatively assigned by comparison with those of some analogous compounds [26-29], Table II.

Nickel chloride and oxide are the products identified at $420^{\circ} \mathrm{C}$ when decomposition is carried out in air and the overall weight loss up to this temperature is $27.08 \%$. When decomposition occurs in nitrogen flow the experimental weight loss is almost the same but a different compound or a mixture that could not be identified is formed. Nevertheless, the X-ray powder diffraction data on thermal analysis residues at $800^{\circ} \mathrm{C}$, both in air or nitrogen, indicate the presence of only nickel oxide [30].

Thermal decomposition of nickel hydroxynitrate is a single-step process (Fig. 2c) that takes place in the temperature range 295 to $380^{\circ} \mathrm{C}$ and is accompanied by a weight loss of $39.24 \%$, yielding nickel oxide as final product. The theoretical value calculated for the reaction $\mathrm{Ni}_{3}(\mathrm{OH})_{4}\left(\mathrm{NO}_{3}\right)_{2} \rightarrow 3 \mathrm{NiO}$ is $39.12 \%$.

The thermograms recorded for nickel hydroxide are similar to those already published [23].

\subsection{X-ray high temperature diffraction studies}

When nickel hydroxychloride is heated under dynamic vacuum $\left(10^{-3}\right.$ torr $)$ in the $\mathrm{X}$-ray high temperature diffraction chamber, it decomposes at about $50^{\circ} \mathrm{C}$ and at $250^{\circ} \mathrm{C}$ the $\mathrm{X}$-ray diagram (Fig. $4 \mathrm{~b}$ ) shows lines that could be indexed with the hexagonal cell parameters given for Type II nickel hydroxychloride [25]. As the temperature increases, nickel oxide diffraction maxima appear and at $400^{\circ} \mathrm{C}$ the diagram is as shown in Fig. 4c. At $600^{\circ} \mathrm{C}$ the recorded diagram consists of lines of nickel oxide and in addition a broad band at $2 \theta=15.7^{\circ}$ is still observed. The nickel diffraction peaks are evident when the temperature reaches $680^{\circ} \mathrm{C}$ (Fig. 4d), and when the temperature is held at $720^{\circ} \mathrm{C}$ for $20 \mathrm{~min}$ nickel is readily obtained as the only product.

Under the experimental conditions already indicated, decomposition of nickel hydroxynitrate starts at about $200^{\circ} \mathrm{C}$ and $\mathrm{NiO}$ diffraction lines start to appear; at $400^{\circ} \mathrm{C}$ they are observed as very broad bands together with the most intense lines of nickel hydroxynitrate (Fig. 5b). The crystallization of nickel oxide increases as the temperature rises and at $500^{\circ} \mathrm{C}$ the diagram only shows the diffraction maxima of nickel oxide as very well-defined peaks (Fig. 5c). As the temperature is increased, the most intense (llll) reflection of nickel metal is observed as a shoulder on the (200) reflection of nickel oxide. Nickel exists from $600^{\circ} \mathrm{C}$ onwards and at $700^{\circ} \mathrm{C}$ there is evidence for the presence of a considerable amount of the metal; it is obtained as the only product on holding the temperature at $700^{\circ} \mathrm{C}$ for about $30 \mathrm{~min}$.

In order to compare the above results, $\mathrm{Ni}(\mathrm{OH})_{2}$ has also been decomposed under the same experimental conditions. The $\mathrm{X}$-ray diffraction pattern of this material is not altered up to $300^{\circ} \mathrm{C}$, a temperature at which nickel oxide is formed as indicated by the very broad bands appearing in the $2 \theta$ intervals where the most intense reflections of nickel oxide are located. At $500^{\circ} \mathrm{C}$ the (1 111$)$ and (200) reflections of nickel metal are observed (Fig. $6 \mathrm{c}$ ), and from this temperature up to $700^{\circ} \mathrm{C}$ their intensities progressively increase as well as the crystallinity of the remaining nickel oxide, which is still observed even if the sample is heated at $900^{\circ} \mathrm{C}$ for $15 \mathrm{~min}$ (Fig. 6e).

\section{Conclusions}

From all the above results it can be concluded that both nickel hydroxychloride or nickel hydroxynitrate can be used as inorganic precursors of nickel when these basic salts are thermally decomposed under particular experimental conditions, yielding in both cases the metal at comparatively low temperatures, especially if nickel hydroxynitrate constitutes the parent material.

When nickel hydroxide is decomposed under the same conditions, the metal is obtained at the lowest temperature $-400^{\circ} \mathrm{C}-$ but it is not the only product since nickel oxide remains as a minority component up to at least $900^{\circ} \mathrm{C}$. 


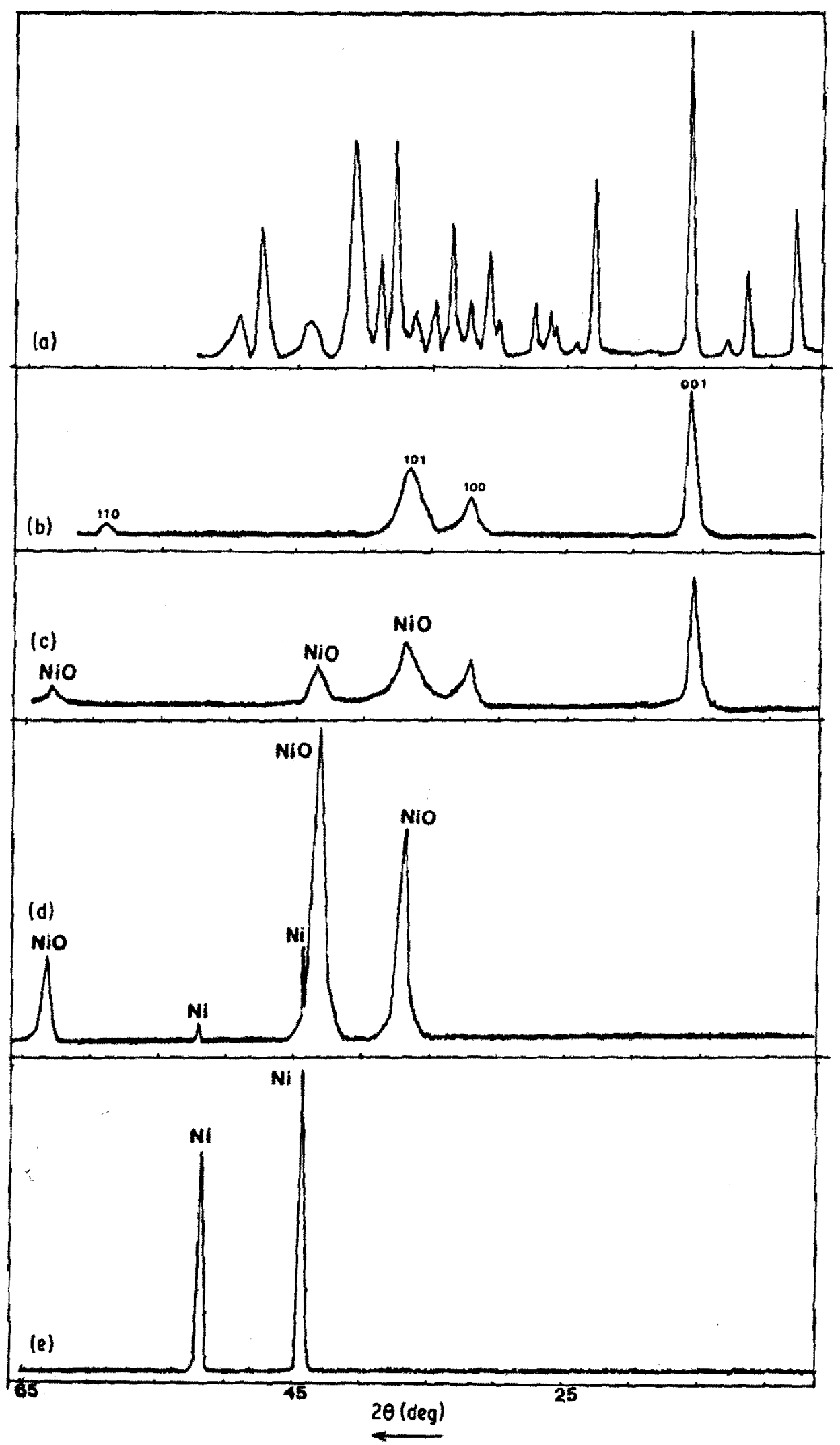

Figure 4 Evolution of nickel hydroxychloride when it is decomposed in the X-ray high-temperature diffraction chamber: (a) unheated; (b) $250^{\circ} \mathrm{C}\left(a_{\text {hex }}=0.317 \mathrm{~nm}, c_{\text {hex }}=0.546 \mathrm{~nm}\right) ;(\mathrm{c}) 400^{\circ} \mathrm{C}$; (d) $680^{\circ} \mathrm{C}$; (e) $720^{\circ} \mathrm{C}, 20 \mathrm{~min}$. 


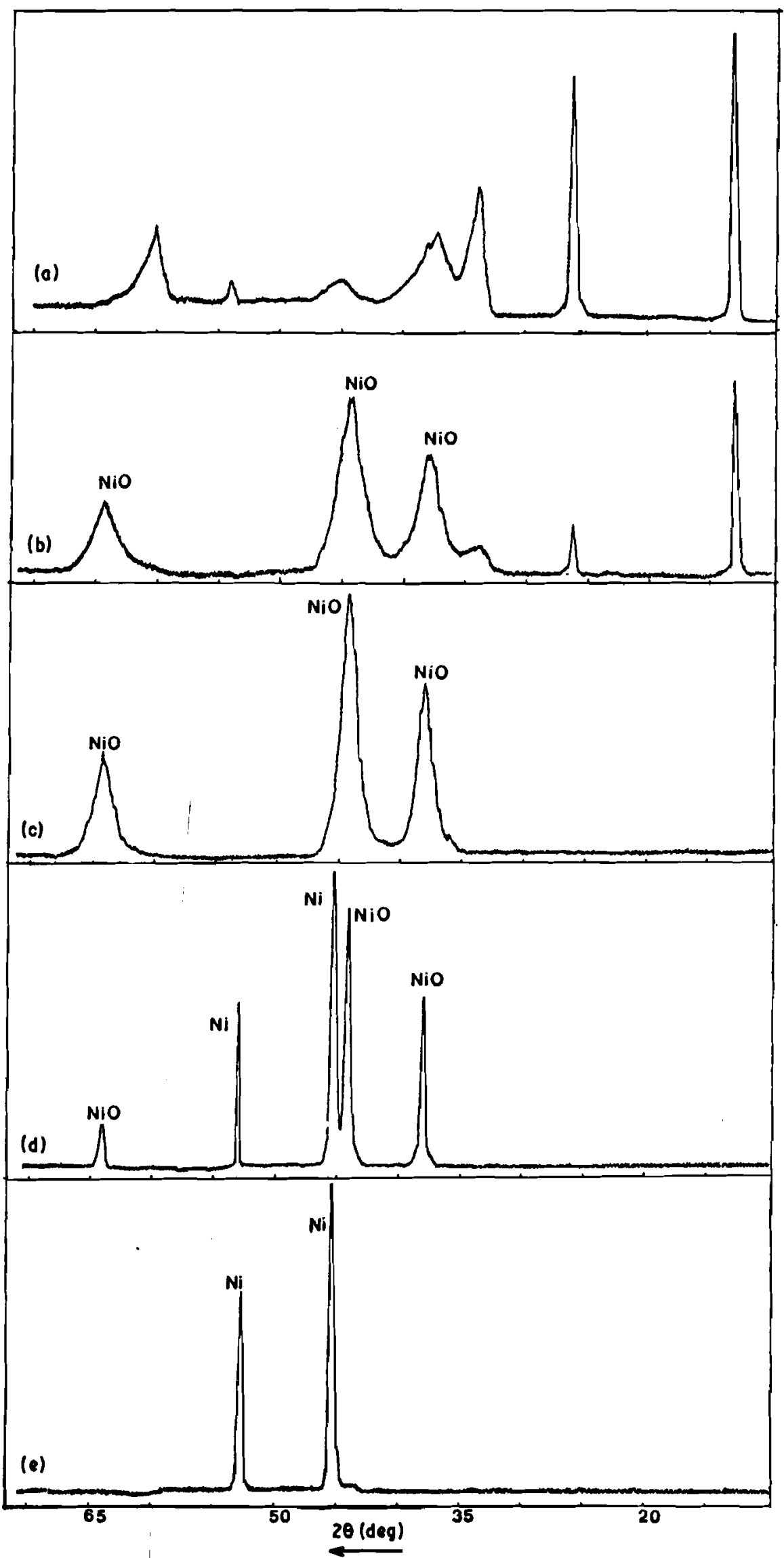

Figure 5 Evolution of nickel hydroxynitrate when it is decomposed in the X-ray high-temperature diffraction chamber: (a) unheated; (b) $400^{\circ} \mathrm{C}$; (c) $500^{\circ} \mathrm{C}$; (d) $700^{\circ} \mathrm{C}$; (e) $700^{\circ} \mathrm{C}, 30 \mathrm{~min}$. 


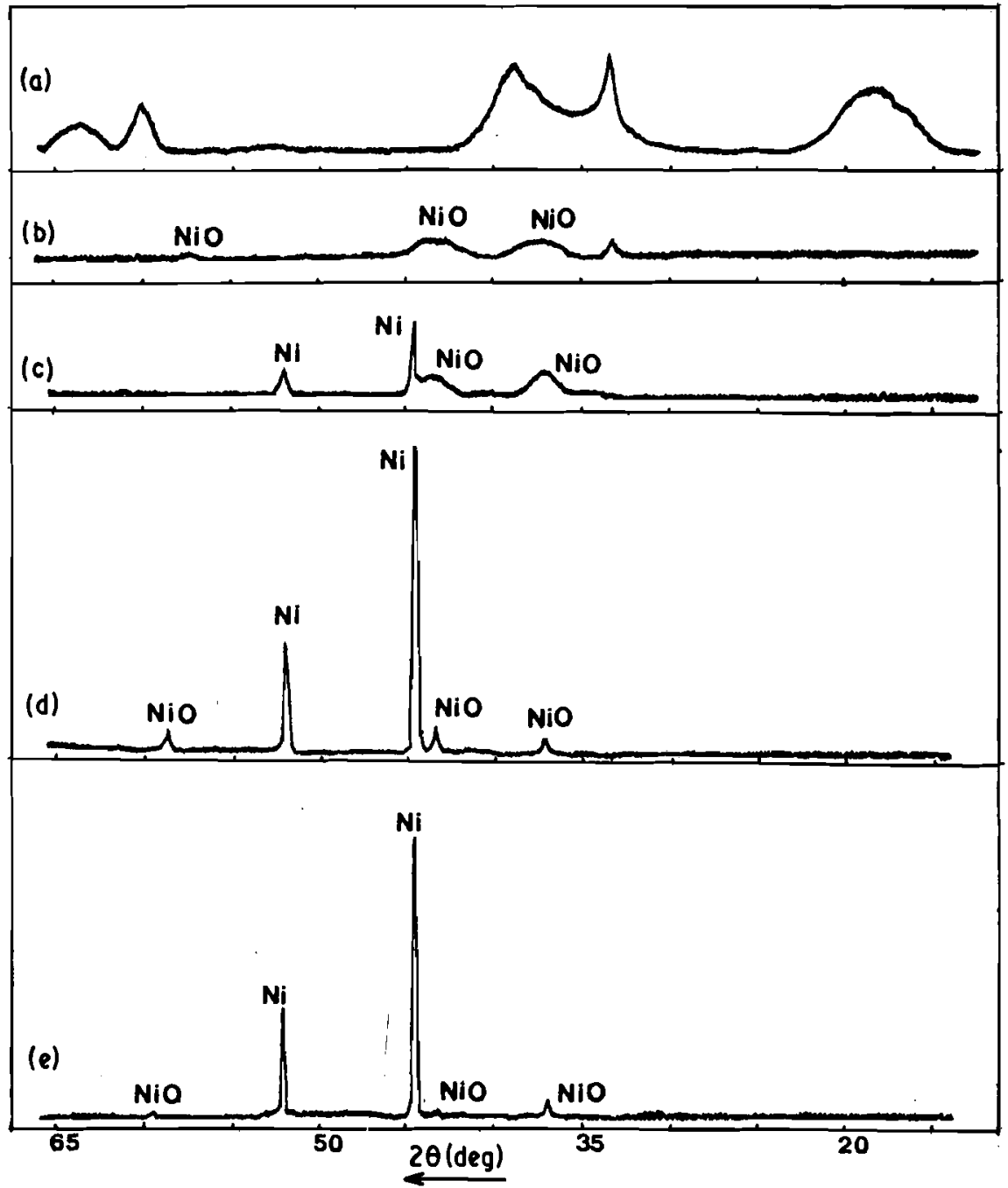

Figure 6 Evolution of nickel hydroxide when it is decomposed in the X-ray high-temperature diffraction chamber: (a) unheated; (b) $400^{\circ} \mathrm{C}$; (c) $500^{\circ} \mathrm{C}$; (d) $700^{\circ} \mathrm{C}$ (e) $900^{\circ} \mathrm{C}, 15 \mathrm{~min}$

From these results it can be noted that it would be worthwhile to use a nickel basic salt, mainly nickel hydroxynitrate, as inorganic precursor in the production of nickel.

\section{References}

1. YU. I. KHIMCHENKO, M. M, KHVOROV and A. S. CHIRKOV, Otkrytiya, Izobret., Prom. Obraztsy, Tovarnye Znaki, 12 (1984) 43, Patent No. 1082567.

2. YU. I. KHIMCHENKO, M. M. KHVOROV, A. S. CHIRKOV and L. G. NADEL, Kolloidn. Zh. 46 (1984) 175.

3. YU. I. KHIMCHENKO, V. P. VASILENKO, L. S. RADKEVICH, V. V. MYALKOVSKII, T. V, CHUBAR and V. M. CHEGORYAN, Poroshk. Metall. (Kiev) No. 5 (1977) 7.

4. B. YA. KRASIL'SHCHIK, B. M. ABRAMZON, M. A. GROBOV and E. M. VIGDORCHIK, Tr. Proekt. Nauch. - Issled. Inst. "Gipronickel" (Gos. Inst. Proekt. Predpr. Nikelevoi Prom.) 57 (1973) 58.

5. A. YA. KIPNIS and N. F. MIKHAILOVA, Otkrytiya, Izobret., Prom. Obraztsy, Tovarnye Znaki 50 (1973) 50.

6. D. M. LLEWELLYN, US Patent No. 3694186 (1972).

7. Idem, S. African Patent No. 7104050 (1972).

8. H. R. FORMAN, Ger. Offen. Patent No. 2133287 (1972).

9. D. M. LlewellyN, Ger. Offen Patent No. 2132950 (1972).

10. D. EVANS and A. B. SIMPSON. Ger. Offen. Patent No. 2133185 (1972).

11. B. S. TSYLOV, A. V. KORENEV and V. S. IVLEV Tsvet. Metal 43 (1970) 26.

12. M. ZVANUT, J. SLIVNIK, A. RIHAR and B. SEDEJ, Technical Report, Nuk1. Inst. "Josef Stefan", NIJS Porocilo, Ljubljana, Yugoslavia, No. P-210 (1967).

13. P. M. PRASAD and P. K. JENA, Met. Trans. 2 (1971)
14. R. L. MOSS, in "Experimental methods in catalytic research", Vol. II, edited by R. B. Anderson and P. T. Dawson (Academic Press, London, 1976) p. 69.

15. O. GARCIA MARTINEZ, P. MILLÁN and R. M. ROJAS, J. Mater. Sci. 21 (1986) 4411.

16. W. FEICTKNECHT and A. COLLET, Helv. Chim. Acta 22 (1939) 1428.

17. D. Weigel, B. IMELIK and P. LAFFite, Bull. Soc. Chim. Fr. 2 (1962) 345.

18. P. GAZELLOT and M. PRETTRE, ibid. 2 (1969) 407.

19. D. LOUER and A. De GUIBERT, J. Mater. Sci. 20 (1985) 3729.

20. Card 22-752, JCPDS International Centre for Diffraction Data (1983), Pennsylvania, USA.

21. Card 14-117, JCPDS International Centre for Diffraction Data (1983), Pennsylvania, USA.

22. T. SATO, T. NAKAMURA and F. OZAWA, J. Appl. Chem. Biotechnol. 25 (1975) 583.

23. M. SAKASHITA and N. SATO, Bull. Chem. Soc. Jpn 46 (1973) 1983.

24. D. W. WESTER, J. MULAK, R. BANKS and W. T. CARNALL, J. Solid State Chem. 45 (1982) 235.

25. W. FEITKNECHT and A. COLlet, Helv. Chim. Acta 19 (1936) 831.

26. P. .TARTRE, Spectrochim. Acta 13 (1958) 107.

27. P. RAMAMURTHY and E. A. SECCO, Can. J. Chem. 48 (1970) 2656.

28. K , NAKAMOTO, "Infrared spectra of inorganic and coordination compounds", 2nd Edn (Wiley-Interscience, New York, 1970) p. 82.

29. J. PASTRNIAK, Opt. Spek 6 (1959) 64.

30. Card 4-0835, JCPDS International Centre for Diffraction Data (1983), Pennsylvania, USA.

Received 4 August

and accepted 22 September 1986 